\title{
FIRST F0OT
}

\author{
Everything as it should be.
}

\section{BY DEBORAH WALKER}

$\mathrm{N}$ ew Year's Eve and it's snowing outside. Of course it is. They switched on the weather machines on 1 December. Snow for the holidays. We're in the living room, waiting for the first foot. The first person through the door who will bring our luck for the year.

Uncle Milo's dozing in his chair. He's as drunk as a skunk. He was never a heavy drinker. But we all have our quotas.

Uncle Milo and Auntie Val live with us. They used to have a nice retirement flat overlooking the harbour. But families should live together.

The lights are dim, the red fairy lights on the Christmas tree are winking and recording, checking that the traditions are being upheld. I wonder if any observers are tuned in. Are we providing good entertainment?

I go to the window, stare out into the street. There's a hundred families, a hundred houses in a circle. A hundred houses with no back doors or windows. There are lights in every sitting room. We're all waiting for our first foot. I can see them, tall dark figures in the cold, waiting to bring our luck.

With a peal of bells from a non-existent church, the year turns.

"Happy New Year," shouts Mother. When the twins jump up and down, shouting in excitement, Mother looks relieved. She'd spent all afternoon coaching them. I smile at her, trying to tell her, that I understand. I really do.

She pats my cheek. "Happy New Year, Brenna."

Auntie Val rouses Uncle Milo. We link hands and sing Auld Lang Syne.

Mother looks towards the door. "Where is he? Where is he?" she whispers.

"It's all nonsense." Uncle Milo's eyes are red and bleary. He strides towards the Christmas tree and glares at it. "It's all nonsense." His words fall like the heavy snow.

I pull the twins closer to me. They're still bewildered, after seeing Santa delivering the presents. Santa shouldn't ooze down the chimney.

\section{$\rightarrow$ NATURE.COM}

Follow Futures:

@ @NatureFutures

f go.nature.com/mtoodm
"I'm okay. I'm okay," he says. "Don't fuss so. Don't," he says, shaking off Auntie Val's offer of help. He sounds as if he hates her.

Auntie Val begins to cry. So do the twins.

"Unseasonal behaviour won't be tolerated." The enforcer's voice fills the room.

Mother says quickly, "But it's traditional for people to lose their rag at this time of year."

"Ensure that it's an isolated incident."

"I will, thank you."

There's a knock at the door. "Answer it, Brenna," says Mother.

I open the door. He's tall and he's dark. Father smiles at me, but he looks puzzled. I feel uneasy. Usually Father's so good at playing his part.

"Where were you?" hisses Mother. "Uncle Milo's had a turn."

Uncle's still on the floor, sobbing.

"I... met someone."

"Just get it over with," says

Mother.

Father holds a handful of silver coins, a lump of coal and a twist of salt. He shouts out: "Happy New Year t'ye! God send ye plenty! Where ye have one pound note, I wish ye have twenty." He passes out the gifts, giving me the salt twist.

I unwrap it and taste the salt with the tip of my finger. Then I let the salt fall to the floor, and quickly shove the wrapper into my pocket. The paper's printed with a red circle: the sign of the resistance. I'd heard rumours but I never thought they could be true. Can anyone fight the enforcers? Can anyone escape this zoo?

Mother gives Father a mince pie. It's dusted with blue sugar. Father looks at it for a moment, before eating it with two quick bites.

Mother sighs. "That's it, then. Let's get to bed."

"Happy New Year, Mother." I hug her.

"Happy New Year, darling."

I help the twins to bed, thinking about the first foot who brings the luck for the New Year. And I'm thinking about the resistance. The New Year brings hope.

Deborah Walker grew up in the most English town in the country, but she soon high-tailed it down to London, where she now lives with her partner, Chris, and her two young children. 